\title{
FOUR POEMS ABOUT PAINTERS AND ONE ABOUT AN EXTRAORDINARY SCULPTOR
}

Peter Belton

Realising Gislebertus' Eve (2019)

And so God created Adam and Gislebertus made his Eve.

A naked Eve he saw in prostrated grief with head in hand.

A tear from her eye rendered forever in cold stone facing away from the weird of her fate and lost children she will bear.

Always another place another time as her arms reach behind.

And she labours with her hands till fruit from the bough becomes a fruit from her womb withal the long naked shadow of sorrow. Aware of affect, we see how she lies with that judgement now. And always the need to cover her head, her paps, her cunt so so. And she must weave herself into a shadow and a reflection that another might ask who she really is and what pain she knows. And how the workings of her day are set in stone-faced law by Allman. Yet another man, Gislebertus, at least saw and recognised. And when attempting to carve a telling he somehow understood.

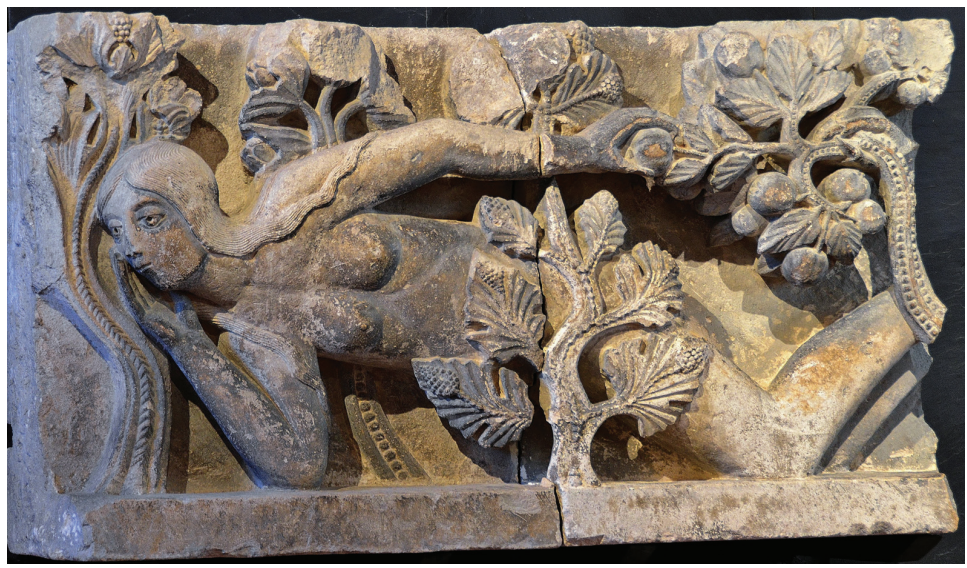

Figure I. Attr. Gislebertus (worked: I I 20-35), Eve. St Lazare Cathedral (north portal), Autun, France. 
Gislebertus was the master carver working on Autun Cathedral, c. I 120-35. The story or legend has it that he carved almost all the figures in the cathedral by himself, and they are truly remarkable as sympathetic portraits of human types. For me, the writer, the most remarkable piece is his depiction of Eve. It may be the earliest rendering of a naked woman in medieval Christian art and, in the judgement of this writer, only Rembrandt's depiction of Bathsheba might be its equal.

The guidebooks tell us the subject of this sculpture is The Temptation of Eve. What the myth does not properly unpack is explanation for the presence of the One-Eyed Trouser Snake and the fecund promise of the apple. "Paps:" archaic Scandinavian/English term for breast or nipple. Modern definition: something soft, mushy, as with slops/food.

Gislebertus' sculpture presents Eve as vulnerable and afraid: aware before the moment of "the fall", whereas the Book of Genesis tells us that awareness and the shame of being aware came only as a consequence of taking the forbidden fruit.

Commedia dell'arte and Watteau's Folly (2020)

Gilles as Pierrot the consumptive clown regards us still withal his heavy immobility, apart yet poised, to be presented above his station as a limewashed statue so near yet so far from us, seeing over, through and beyond to when his moment becomes our moment. Around Pierrot's feet, beneath his plinth and beneath the wall, discover confused lovers Leandre and Isabelle who cannot answer to Harlequin and Columbine. No trickster and his wily-witted paramour here. They slip to exit stage left while the Doctor and his braying ass demand we pay heed to their dialogue, a hollowing of forms into pufferies of words to be parried by that buffoon Captain Saltimbanque on the gallant point of his word. And so, we read how substitution plays a frivolous game, apparently, to an unseen Rococo audience where a memorial to the genius of a dying man might be fashioned through and with insights arising from the converging states of the artist and the clown. 


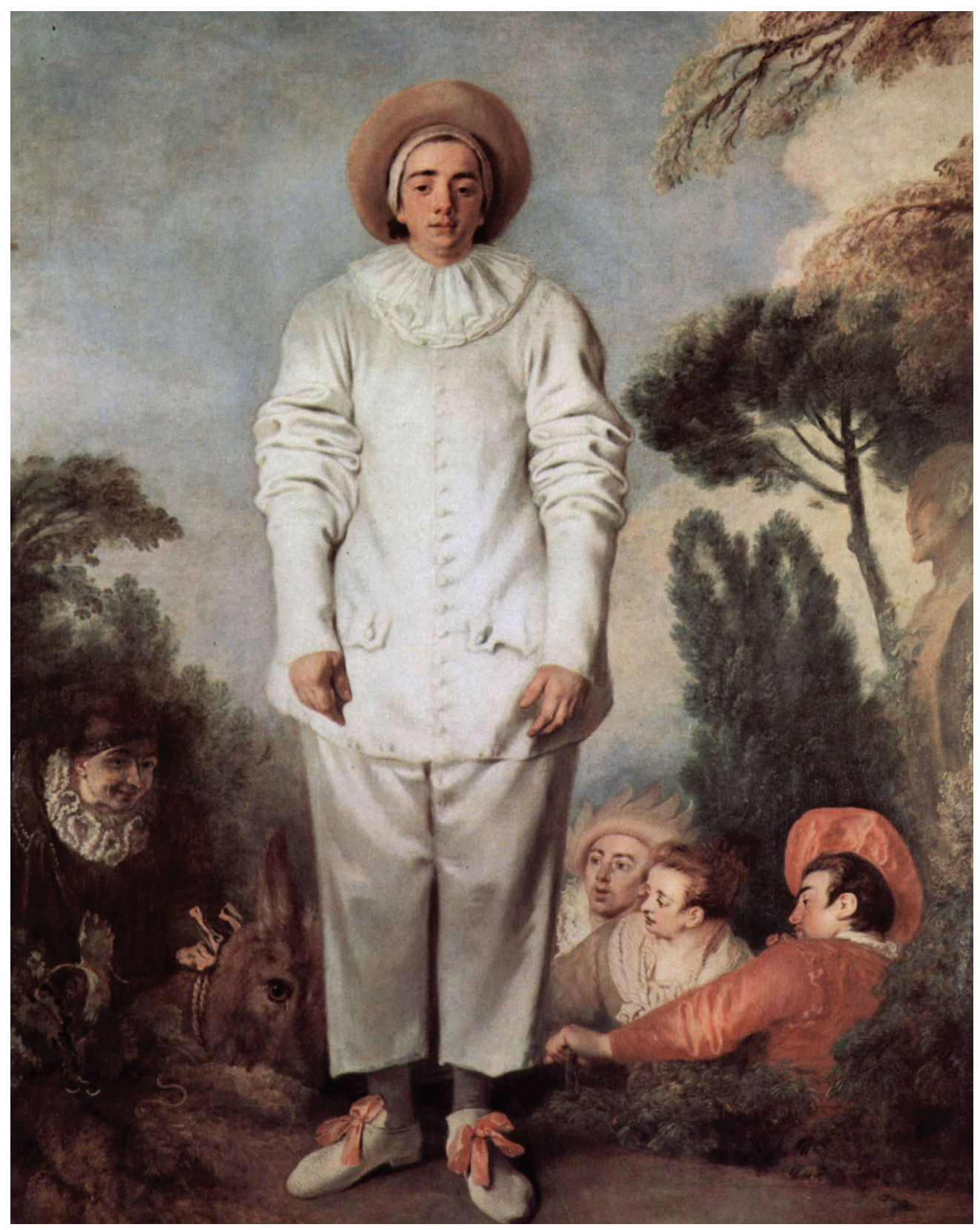

Figure 2. Jean-Antoine Watteau, Gilles (or Pierrot) and Four Other Characters of the Commedia dell'arte, c. 17।8-19.

Picasso was merely stating a truism when he said that all painting is self-portrait. Watteau suffered from delicate health and died young from consumption (tuberculosis) at the age of 36 during the flowering of French Rococo culture. He has left us with a legacy of some of the most psychologically insightful drawing. His images have a sly kindness and understanding of how the most nuanced gesture can signal a story, with all its pathos and its irony. 
Rossetti, his Brotherhood and the spirit of no matter (2020)

Why do I write about Dante Gabrielle Rossetti, that bright shit who slipped his charming words in between her breasts, beneath her hair? Elizabeth, Sally or Jane, no matter.

Morris up to his elbows with aniline dyes and the seductions of diaphanous colour, blue, mauve, pale citrus green, and apricot pink. Not her breasts.

Married to his work, she said.

While Dante-Gabrielle rubs saffron balms into her folding self and Elizabeth plays at Ophelia's floating suicide, and by playing-so-fully just finds that slip of becoming laudanum later. No matter.

And, Holman Hunt's newly discovered Sally Cornforth, she with the fiery golden hair, surrounded by signifiers and murmuring mirrors. No Awakening Conscience for her. To die abandoned and colourless.

And so, these obsessions of gentlemen will be pulled into the withdrawing rooms in which the lady ornaments may fret until displaced from the vessels of their being by younger flowers. No matter. 


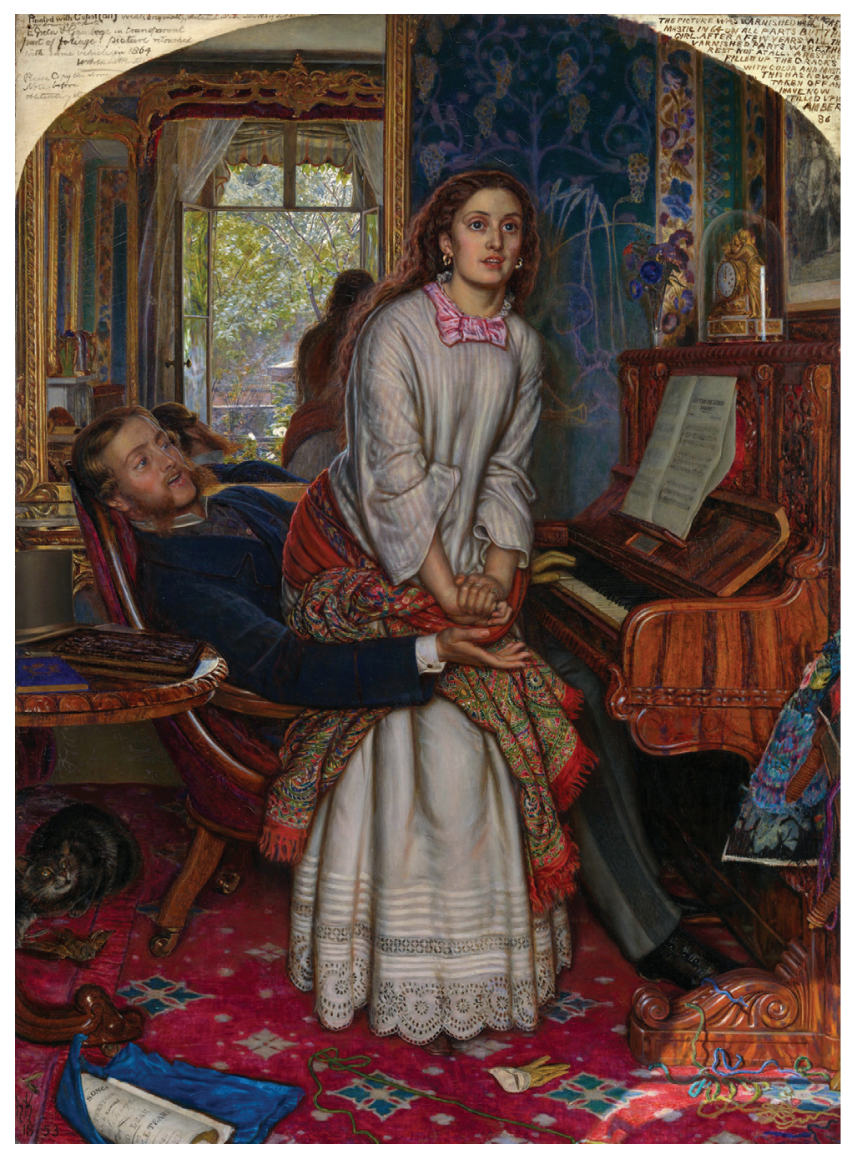

Figure 3.William Holman Hunt, The Awakening Conscience, 1853, oil on canvas, $76 \times 56 \mathrm{~cm}$.

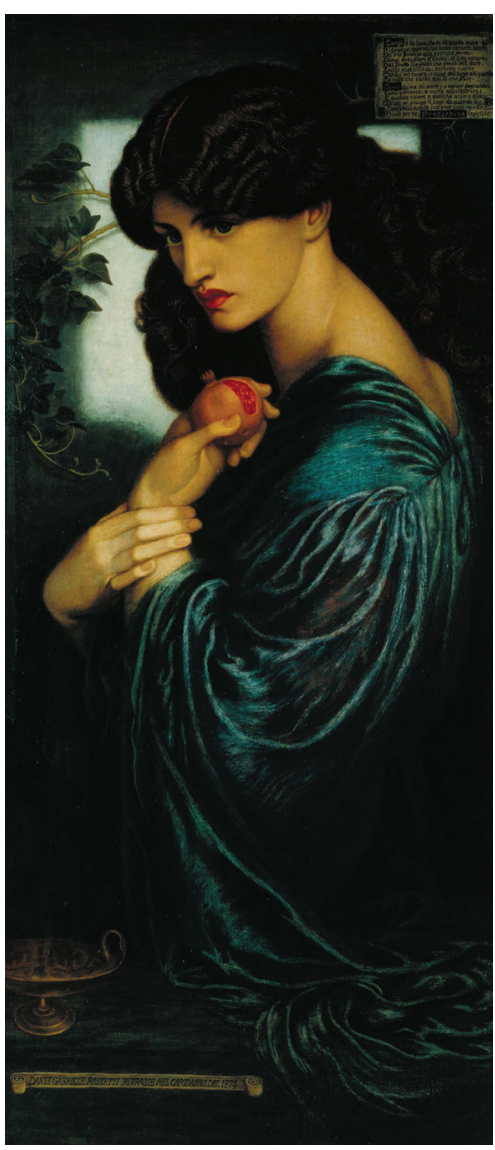

Figure 4. Dante Gabriel Rossetti, Proserpine, 1874, oil on canvas, $125 \times 61 \mathrm{~cm}$.

The artists referred to here were members of the Pre-Raphaelite Brotherhood: mid-Victorian romantics who were obsessed with fidelity to natural appearances in their renderings, if not exactly so in their 'gallant' pursuits. These men were the products of comfortable middle-class wealth and entitlement and, being gallant, they pursued attractive working-class girls who became their models and paramours - as Jane Morris was to Rossetti. With the exception of Jane Burden, who remained married to William Morris, these women were all abandoned and returned to poverty at some later stage.

Proserpine was the Roman goddess associated with the cult and mysteries associated with the production of wine and was also linked to Ceres, goddess of cereals and grain. Her Greek predecessor was Persephone. The model was Jane Burden, wife of William Morris. 
Three Pastoral Moments (2020)

To start with a Crisp quote: "A Romantic is one who describes a World better than it is; a realist is a pessimist, but the one who describes the world as it is we call a satirist." Thanks Quentin.

It declaims; this depiction of the Hireling Shepherd by William Holman Hunt.

Discover the heady intensity of summer colour and robust midday shadows.

Pan the seducer has set alight corn-coloured hair, comfortable full-bellied sheep, meadow flowers and lush liverworts in which a muscular young man, ruddily warm, is reaching over from behind, into the woman. She leans back into him.

Strong in body, this English Ceres is dressed in a loose fashion with bare feet touching naked into ponded water.Teasing. And so, she allures with apples and a spring lamb in her lap.And so, fascinated with their work; we might sit and watch for hours.

Hay. Is this real? Hey there, Jules Bastien-Lepage, what have we really got here? A depiction; the bitter end of summer where the mown hayfields register a grey mauve in the wobble of sweat and stubble. A roughly shaven tired face, taut and dry. Beside an empty pot, or billy, are the colours of poverty and hand-me-down people. Ragged man flat on his back resting with hat drawn across his eyes as if to deny the moment or any moment. A young woman sits splayed beside him. She is bent forward from carrying and is now staring out, weary and vacant as her aunts might look when admitting to their mending and toil; always over and under.And, we see there are splits and holes in the soles of her shoes. What's more ....

Certainly not bucolic, perhaps ironic, this Dejeuner sur l'herbe in a closed distance. Edouard Manet's almost undressed woman hovers in a pool of liquid pigment, and someone might remember Rembrandt's Bather. And, there are signs of a careless picnic which foregrounds another woman sitting stark naked beside and apart from two wellpresented men. Their conversation is clubbish, insouciant and alcohol-fuelled. Having undressed her, they ignore her and so she must pass a level gaze over and out toward us, her audience. Nothing plein-air here and certainly no romance. It rains outside and so we might drink with the humours which are being staged in the artifice of somebody's studio. 


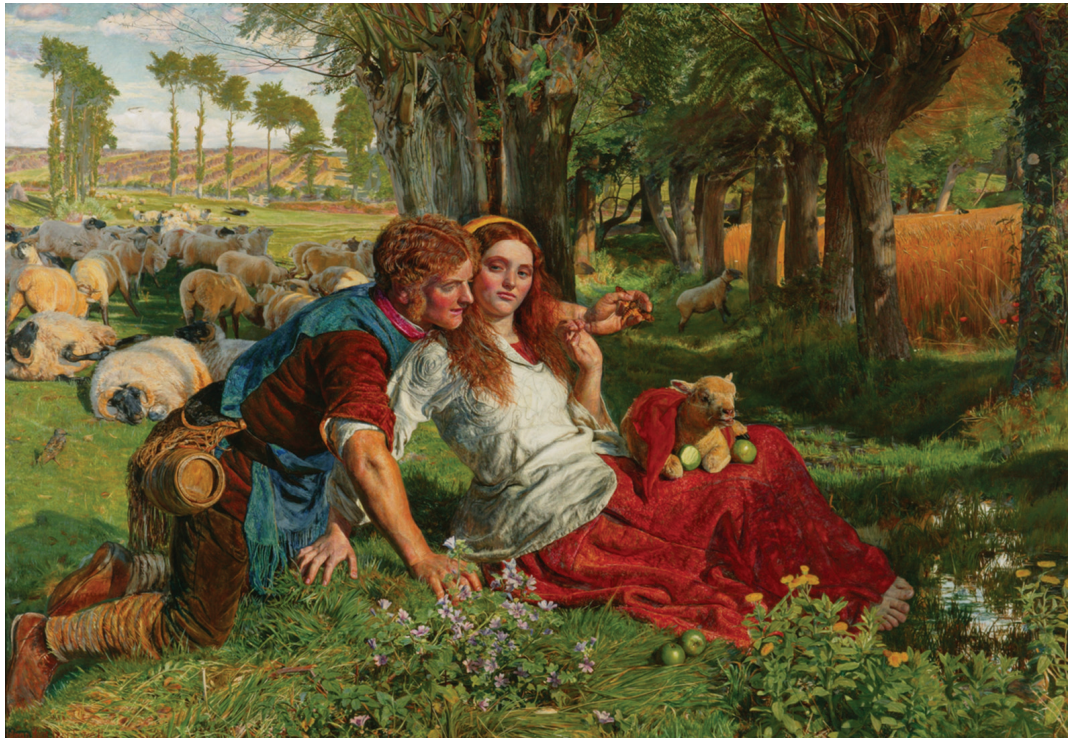

Figure 5.William Holman Hunt, The Hireling Shepherd, I85I, oil on canvas, $76 \times 110 \mathrm{~cm}$.

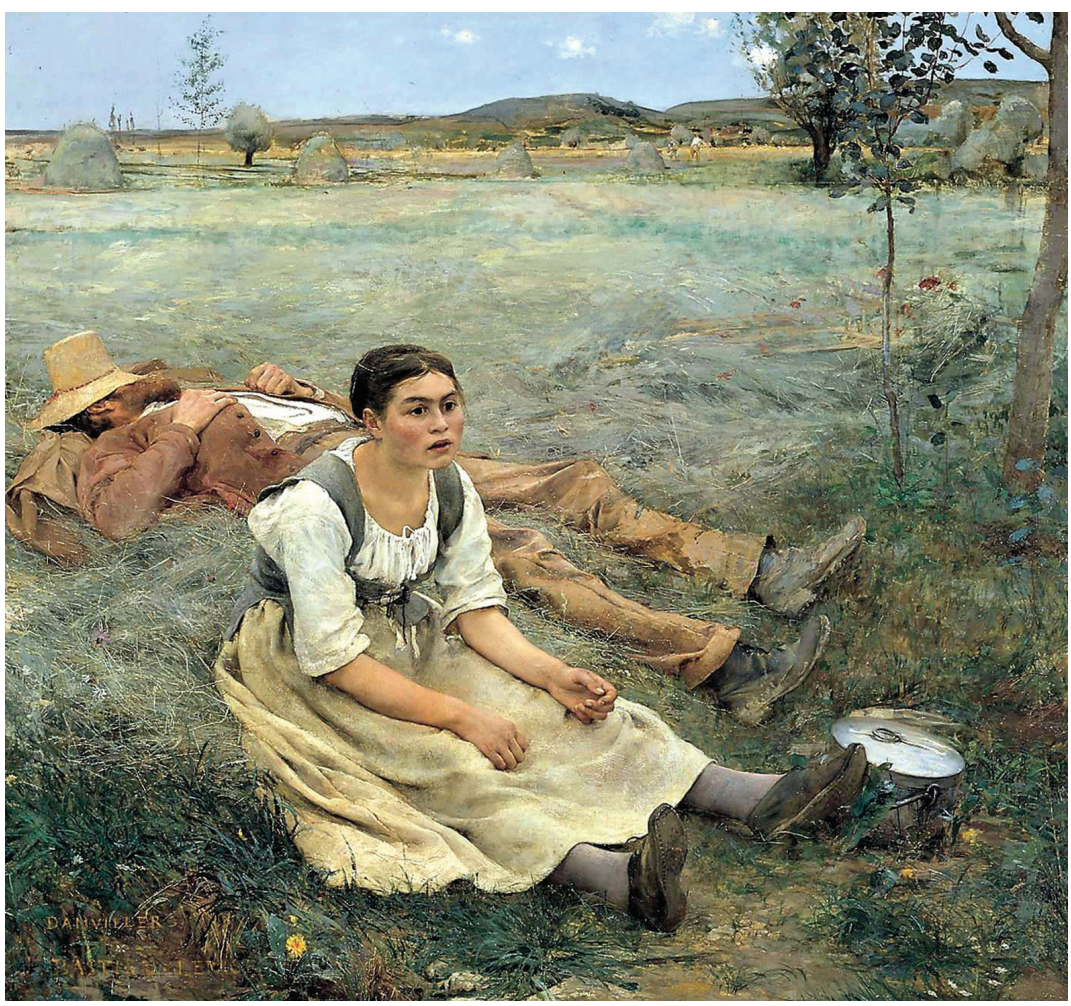

Figure 6. Jules Bastien-Lepage, Haymakers (Les Foins), I877, oil on canvas, $160 \times 195 \mathrm{~cm}$. 


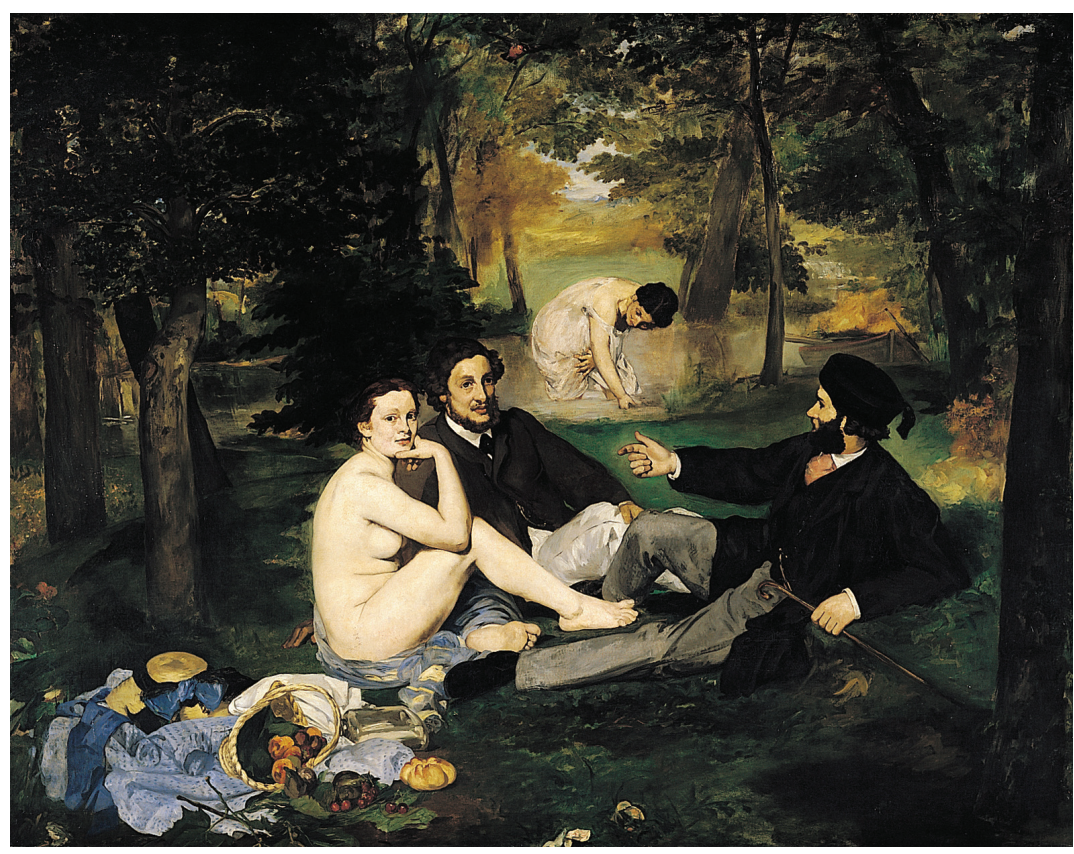

Figure 7. Edouard Manet, Le Dejeuner sur l'herbe (The Picnic on the Grass), I863, oil on canvas, $208 \times 265 \mathrm{~cm}$.

Holman Hunt drew censure from a Victorian public and critics for his depiction of a Hireling Shepherd who has been distracted from his work. In this instance, the model for this distraction was Emma Watkins, who followed the artist when Hunt returned to London from Ewell in rural Surrey. Hunt had been painting alongside fellow Pre-Raphaelite artist John Everett Millais, who was working at the same time on his painting of (the death of 'Ophelia.'The two paintings could have not been more unalike in their project. The subject of Millais' painting, taken from Hamlet, one of the greatest plays in English literature, attracted widespread admiration, whereas Hunt's depiction of the shepherd and his paramour was attacked for its "vulgarity", its portrayal of indolence and its ruddy, rustic and uninhibited sexuality. The Hireling Shepherd was finished in London and first exhibited in I85I. It is now in the collection of the Manchester Art Gallery.

Jules Bastien- Lepage painted his Haymakers (Les Foins) in 1877. In his short life he had a meteoric rise to fame as a social realist painter, pushing away from the comfort of Impressionist subjects, which we now see as representative of the 1870s. It is too easy to overlook the empathetic depictions found in social realist art of this time in France, Germany and Holland. This painting is a fine example of that genre. It is now in the collection of the Museum d'Orsay, Paris.

Le Dejeuner sur l'herbe, painted by Edouard Manet and exhibited in the Salon des Refusés in 1863, is one of the most cited paintings in any discussion about the origins of modern art. At the time of its making, it was, like so many of Manet's works, castigated for its shocking affrontery. Manet's close friend Victorine Meurant, herself a painter of repute, was his model, and we might reflect on their complicity in taking a poke at bourgeois attitudes toward being seen to be proper.The entitlement of the two well-dressed men, their insouciance in the presence of two undressed women, set out to shock. Victorine was also the model for Manet's painting Olympia, another cause de scandale and at the same time a "succès de scandale." Both paintings can be found in the Museum d'Orsay, Paris. 


\title{
Poaching humour offline with Karl Hubbuch (2020)
}

\begin{abstract}
Weimar, 1925, when humour is bitten into by hunger, so like the cutting edges of his paper to draw thin lines of blood beneath the nails. Sleeves rolled up for business, the shirted man points his knife. Somehow off-sider has deep pockets and deeper eyes and cold sharp hands.
\end{abstract} The way everything is drawn; so sharp and clear as cutting cold. The broken house becomes a ripped open carcase to reveal a thrust of wall, a pointed blade into the night with trappings of wire netting. Yet, in this setting hunted ducks somehow elude all. Nowhere in this scene to be seen at all at all. And so Karl's hungry line explores the page with recollection, anticipation and a growling belly.'

During the hungry years of the Weimar Republic in Germany, Karl Hubbuch was one of the artists associated with Die Neue Sachlichkeit, "The New Objectivity" movement. Artists associated with the movement included his close friend George Grosz, Max Beckmann, Otto Dix, Christian Schad and Rudolf Schlichter. Very often satirical in their practice, they came to the notice of the National Socialists and became targets. From 1933 these artists, including Hubbuch, were dismissed from teaching posts and forbidden to practice. Hubbuch died in 1978.

Peter Belton has been a teacher of art history, theory and studio practices. Recent poetry, about artists, published in Landfall 240 and 24I have been about Vincent Van Gogh's Starry Night and Ralph Hotere's mural for Auckland Airport, which was given the name Kuaka. Scope Art\&Design 13, 2013 presented Peter's poems about Lorca (poet), Rembrandt, Schwitters, Ernst, Friedrich, Pearson, Piero della Francesca, Picasso and Frances Hodgkins.

I Karl Hubbuch, Duck Poachers, 1925, pencil and watercolour on paper, $43 \times 43 \mathrm{~cm}$. Duck Poachers is listed as The Duck Robbers in the collection of The Staatsgallerie, Stuttgart, graphic collection. 